\title{
Power Measurement Model Optimization using MATLAB
}

\author{
Ara Jyllian A. Abello, Gabrielle Francesca Y. Domingo, Maria Jamelina T. Joven, Samantha Alexis S. Malubay \\ De La Salle University, Manila \\ 2401 Taft Ave., Malate, Manila 1004, \\ Philippines, ara_abello@dlsu.edu.ph
}

\begin{abstract}
Measurement of Power is circuits is important. It is used to determine the efficiency of the system. There are different types of loads. One of them is a three-phase load. Three phases of electric power are the usual method of alternating current transmission and distribution. This method is a type of polyphase system and is most commonly used in electrical grids to transfer power. An advantage of three-phase systems over single-phase systems is the power delivered is constant, it gives higher output, has a higher power factor, has uniform torque and it requires fewer conductors. However, these systems cannot be measured easily. These systems require two or more wattmeter when being measured. This research will develop a MATLAB Optimization model to measure power in three phase circuits. A database for power capacity will be developed and optimization algorithms will be applied to it.
\end{abstract}

Key words: Power Measurement, Optimization, Three Phase Systems, MATLAB.

\section{INTRODUCTION}

The two-wattmeter method of power measurement can be used to measure the power in a three-phase wye or delta-connected system, regardless if it is balanced or unbalanced [1,2]. In this method, the current coils of the wattmeter are connected with any two lines, while the potential coil of the wattmeter is connected to a third line [3, 4]. The wattmeter connections for a wye and delta connected load are shown in the figure below.

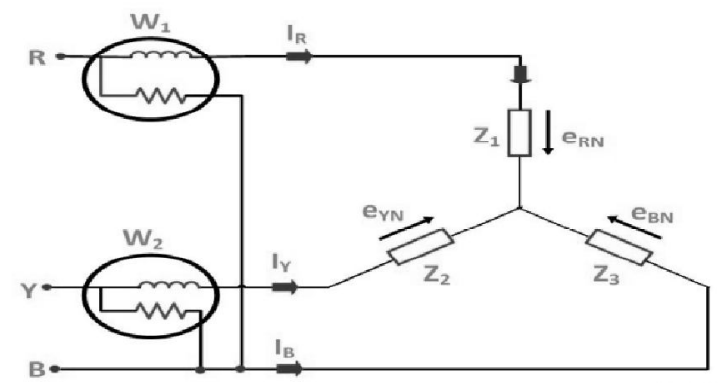

Figure 1: Two Wattmeter Connections of a Wye-Connected Load [5]

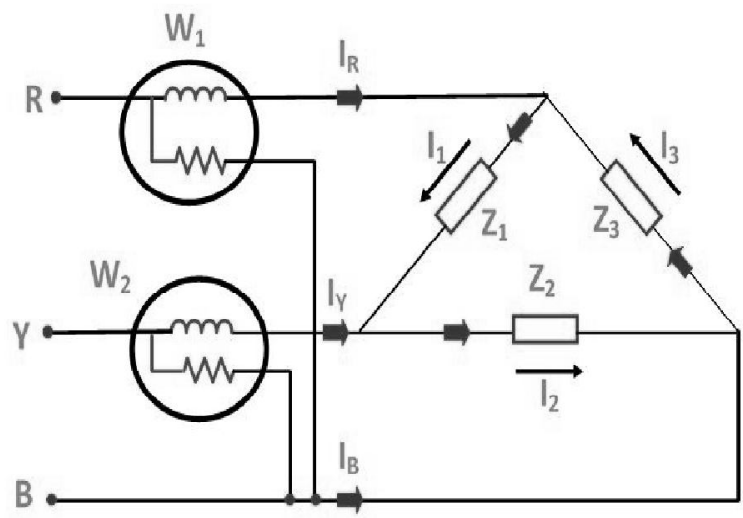

Figure 2: Two Wattmeter Connections of a Delta-Connected Load [5]

Given the circuits of the two-wattmeter method in three-phase wye connection in Figure 1, instantaneous current, potential difference, and power measured for each of the wattmeter connected can be solved using the equation in the table below.

Table 1: instantaneous current, potential difference, and power measured for each of the wattmeter connected can be solved using the equation

\begin{tabular}{|c|c|c|}
\hline & Wattmeter 1 (R) & Wattmeter $2(\mathrm{Y})$ \\
\hline $\begin{array}{l}\text { Instantaneous } \\
\text { Current }\end{array}$ & $\square_{\square 1}=\square_{\square}$ & $\square_{\square 2}=\square_{\square}$ \\
\hline $\begin{array}{l}\text { Instantaneous } \\
\text { Potential } \\
\text { Difference }\end{array}$ & $\square_{\square I}=\square_{\square \square}-\square_{\square \square}$ & $\begin{array}{l}\square_{\square l} \\
=\square_{\square \square}-\square_{\square \square}\end{array}$ \\
\hline $\begin{array}{l}\text { Instantaneous } \\
\text { Power Measured }\end{array}$ & $\begin{array}{l}P_{W 1} \\
=\square_{\square}(\square \square \square \\
-\quad \square \square \square \\
\square_{\square l}=\square_{\square}\left(\square_{\square 1}\right)\end{array}$ & $\begin{array}{c}\square_{\square 2}= \\
\square_{\square}\left(\square_{\square \square}-\square_{\square \square}\right) \\
\square_{\square 2}=\square_{\square}\left(\square_{\square 2}\right)\end{array}$ \\
\hline Total Power & \multicolumn{2}{|c|}{$\begin{array}{c}\square_{\square}=\square_{\square I}+\square_{\square 2} \\
\square_{\square}=\square_{\square}\left(\square_{\square \square}-\square_{\square \square}\right)+\square_{\square}\left(\square_{\square \square}\right. \\
\left.\quad-\square_{\square \square}\right) \\
\square_{\square}=\square_{\square} \square_{\square \square}+\square_{\square} \square_{\square \square}-\square_{\square \square}\left(\square_{\square}\right. \\
\left.\quad+\square_{\square}\right) \\
\square_{\square}=\square_{\square} \square_{\square \square}+\square_{\square} \square_{\square \square}+\square_{\square} \square_{\square \square}\end{array}$} \\
\hline
\end{tabular}


Meanwhile, the instantaneous current, potential difference, and power measured for each of the wattmeters in a delta-connected system as shown in figure 2 can be solved using the equation in the table below.

Table 2: Delta-connected system equations

\begin{tabular}{|c|c|c|}
\hline & Wattmeter $1(\mathrm{R})$ & Wattmeter $2(\mathrm{Y})$ \\
\hline $\begin{array}{l}\text { Instantaneous } \\
\text { Current }\end{array}$ & $\begin{array}{l}\square \square l=\square_{\square} \\
=\square_{1}-\square_{3}\end{array}$ & $\begin{array}{l}\square_{\square 2}=\square_{\square} \\
=\square_{2}-\square_{1}\end{array}$ \\
\hline $\begin{array}{l}\text { Instantaneous } \\
\text { Potential Difference }\end{array}$ & $\square_{\square l}=\square_{\square \square}$ & $\square_{\square l}=\square_{\square \square}$ \\
\hline $\begin{array}{l}\text { Instantaneous Power } \\
\text { Measured }\end{array}$ & $\begin{array}{l}\square \square 1 \\
=\square_{\square \square}\left(\square_{1}-\square_{3}\right) \\
\square_{\square l}=\square_{\square}\left(\square_{\square \square}\right)\end{array}$ & $\begin{array}{l}\square_{\square 2} \\
=\square_{\square \square}\left(\square_{2}-\square_{1}\right) \\
\left.\square_{\square 2}=\square_{\square}\left(\square_{\square \square}\right)\right)\end{array}$ \\
\hline Total Power & \multicolumn{2}{|c|}{$\begin{array}{c}\square_{\square}=\square_{\square l}+\square_{\square 2} \\
\square_{\square}=\square_{\square \square}\left(\square_{1}-\square_{3}\right)+\square_{\square \square}\left(\square_{2}-\square_{l}\right) \\
\square_{\square}=\square_{1} \square_{\square \square}+\square_{2} \square_{\square \square}-\square_{3} \square_{\square \square} \\
-\square_{1} \square_{\square \square}\end{array}$} \\
\hline
\end{tabular}

The power measured by the two-wattmeter method at any instant is equal to the instantaneous power absorbed by the three loads connected in three phases $[6,7,8]$. This power is the average power drawn by the load since the wattmeter reads the average power due to the inertia of their moving system. The power configuration of the system will follow the design of [9]. The output can also be placed in a database following the configuration of [10].

To find the power in a circuit without relying on finding the voltage, current, or total impedance, one can use a wattmeter [11]. A wattmeter is an electronic device that measures the power in a given circuit. Inside a wattmeter, there are two coils. One is connected in series with the circuit and the other is connected in parallel [12]. The coil in series with the circuit is called the current coil. Here, the current from the circuit passes through. On the other hand, the coil in parallel with the circuit is called the voltage coil [13]. Here, the voltage from the circuit drops. As the current passes through the current coil and as the voltage drops at the voltage coil, the needle on the wattmeter deflects [14]. How much the needle deflects depends on the product of the current passing through the current coil and the voltage dropping at the voltage coil $[14,15,16,17]$. As one can see, this is the formula for power, $P=V I$.

For three-phase circuits, there are two methods in using wattmeters; the three-wattmeter method and the two-wattmeter method. In the three-wattmeter method, three wattmeters are used. Each wattmeter is connected to each of the phases. The results of each wattmeter will be added together to get total power.

$$
P_{T}=P_{a b}+P_{b c}+P_{c a}
$$

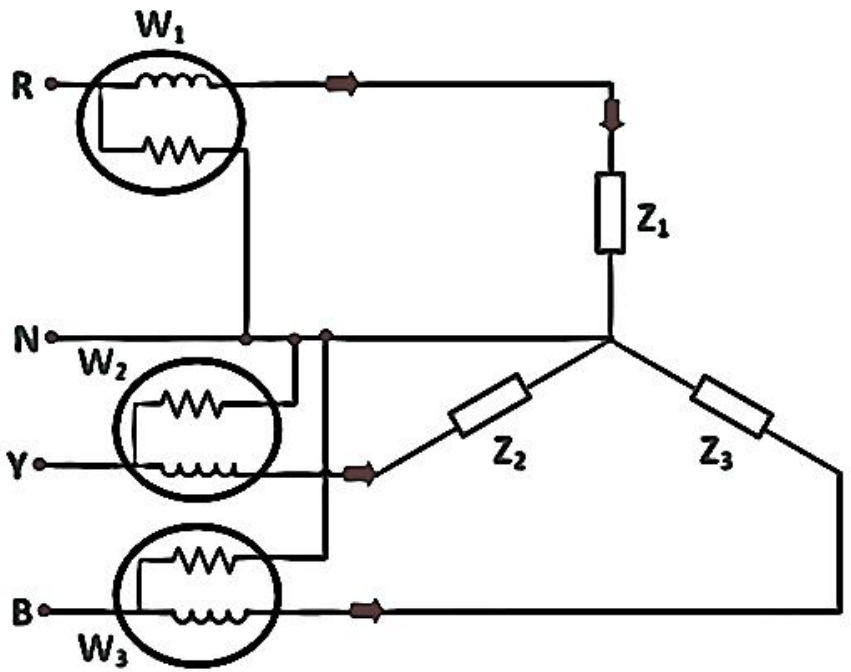

Figure 3: Three wattmeters connected to a wye-connected load [18]

For the two-wattmeter method, two single-phase wattmeters are used to evaluate the three-phase power. There will be times when the data is measured is vague in the database. When this occurs the Logic Scoring of Preference (LSP) can be used $[19,20]$. The data could also be send via usb in the system [21].

More specifically, adding the measurement of two single-phase wattmeters will result in the measurement of three-phase power $[22,23]$. The two-wattmeter method has many advantages e.g. it can be applied to either balanced or unbalanced loads, two wattmeters are used to measure the three-phase power instead of three, and the neutral line for wye-connected loads are not needed to connect the wattmeters [24].

$$
P_{T}=P_{a c}+P_{b c}
$$

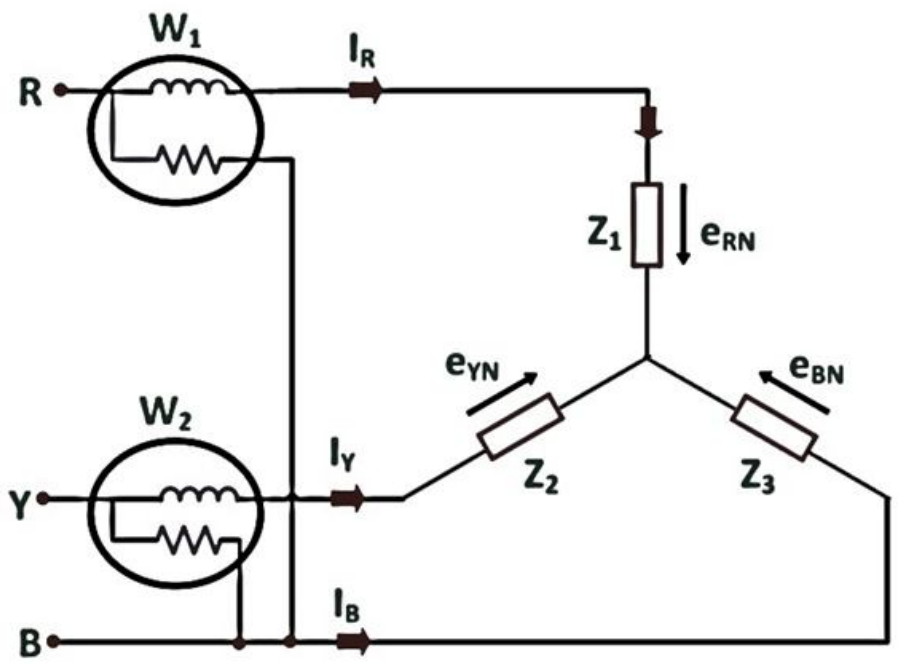

Figure 4: Wattmeters connected to a wye-connected load 
The measured values can be placed in a database and optimized using spatial optimization techniques, Neural networks [26,27,28] and Fuzzy Logic [29, 30].

\section{DATA AND RESULTS}

\subsection{Matlab Input Code}

1. Create a MATLAB script and call it function delta. $\square$ function delta

2. Determine the phase and line voltages from the circuit by representing the inputs of the resistor values as $\mathrm{Ra}, \mathrm{Rb}$, and $\mathrm{Rc}$, and the voltage values as $\mathrm{Va}, \mathrm{Vb}$, and $\mathrm{Vc}$.



3. Convert the delta-connected load to a wye-connected load. Represent the result as Rd.

$$
\mathrm{Rd}=\mathrm{Ra} / 3 \text {; }
$$

4. Solve for the values of Vac, and Ptwo or the resulting power using two wattmeter method.

$$
\begin{aligned}
& \mathrm{Vac}=\mathrm{Va}^{\star} \operatorname{sqrt}(3) ; \\
& \text { Ptwo }=\left(\operatorname{Vac}^{\wedge} 2\right) / \mathrm{Rd} ;
\end{aligned}
$$

5. Display the formula to solve Ptwo and the resulting power using two wattmeter method.

$$
\text { fprintf ('Ptwo= (Vac^2)/\% } \left.1 \backslash \mathrm{n}^{\prime}, \mathrm{Ra}\right) \text {; }
$$

fprintf('Power using two wattmeter method $=\frac{\circ}{6} .2 \mathrm{f} \backslash \mathrm{n}$ ', Ptwo);

FSolve for the power using three wattmeter method. Represent this as Pthree.

$$
\text { Pthree }=\left(3 *(\mathrm{Va})^{\wedge} 2\right) / \mathrm{Rd} \text {; }
$$

6. Display the results of Pthree, as well as the formula used to solve it.

fprintf('Pthree $\left.=\left(3^{*}(\mathrm{Va}) \wedge 2\right) / \% \mathrm{o} \backslash \mathrm{n}^{\prime}, \mathrm{Ra}\right)$;

fprintf('Power using three wattmeter method $=\frac{\circ}{0} .2 f \backslash n$ ', Pthree) ;

\subsection{For a Wye connected circuit}

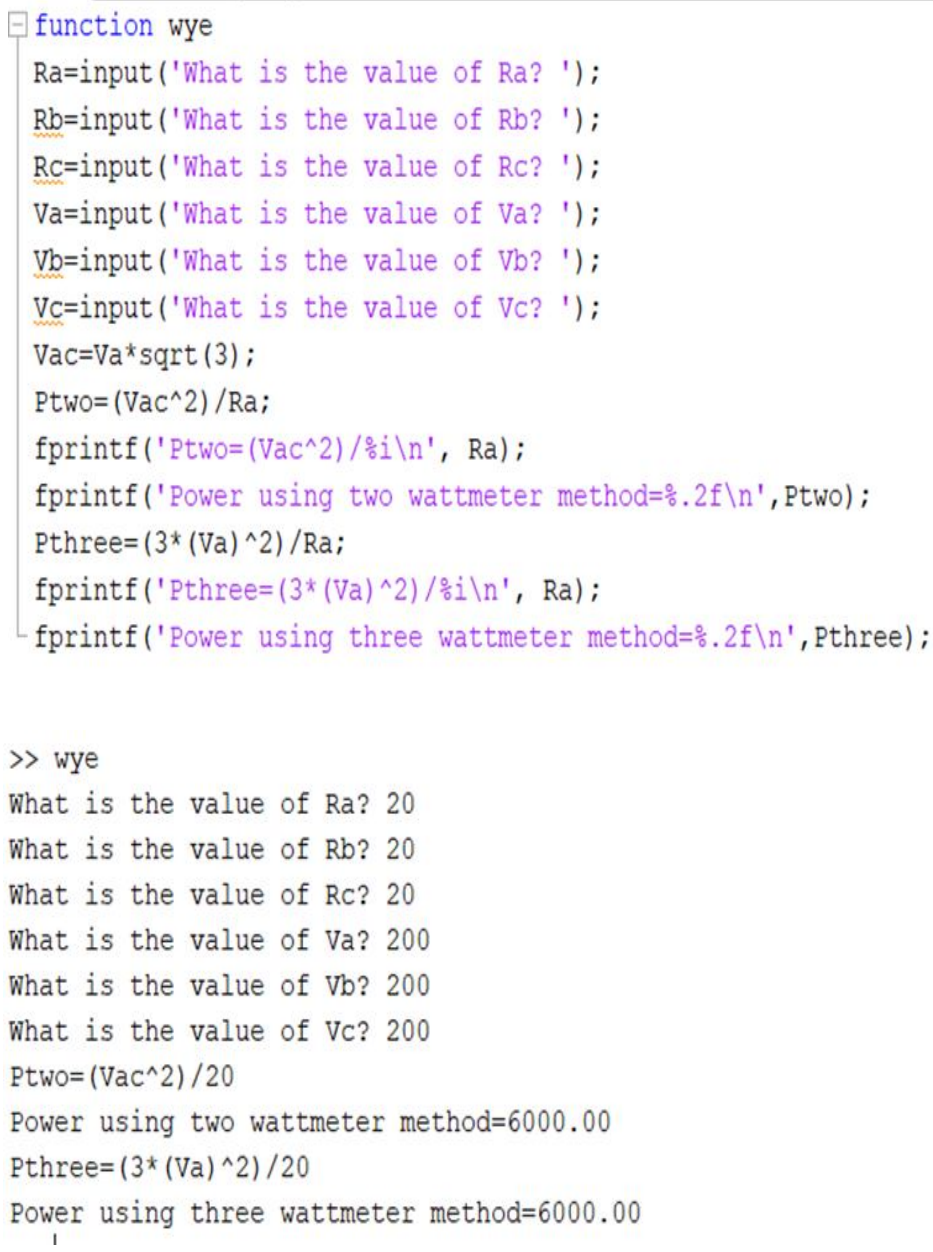

\subsection{For a Delta-connected circuit}

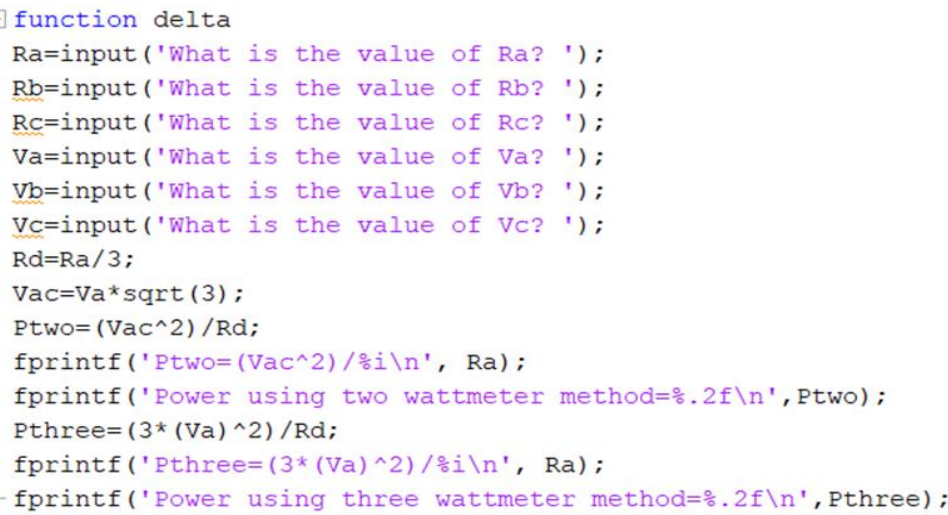




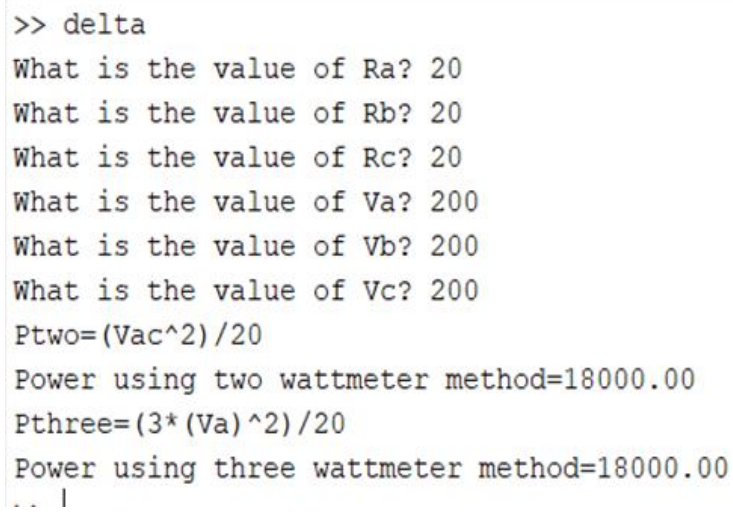

\subsection{Rough Set Theory Data output}

Rough Set Theory was developed by Palwak in 1982 [31]. It can be used to find missing or incomplete information.

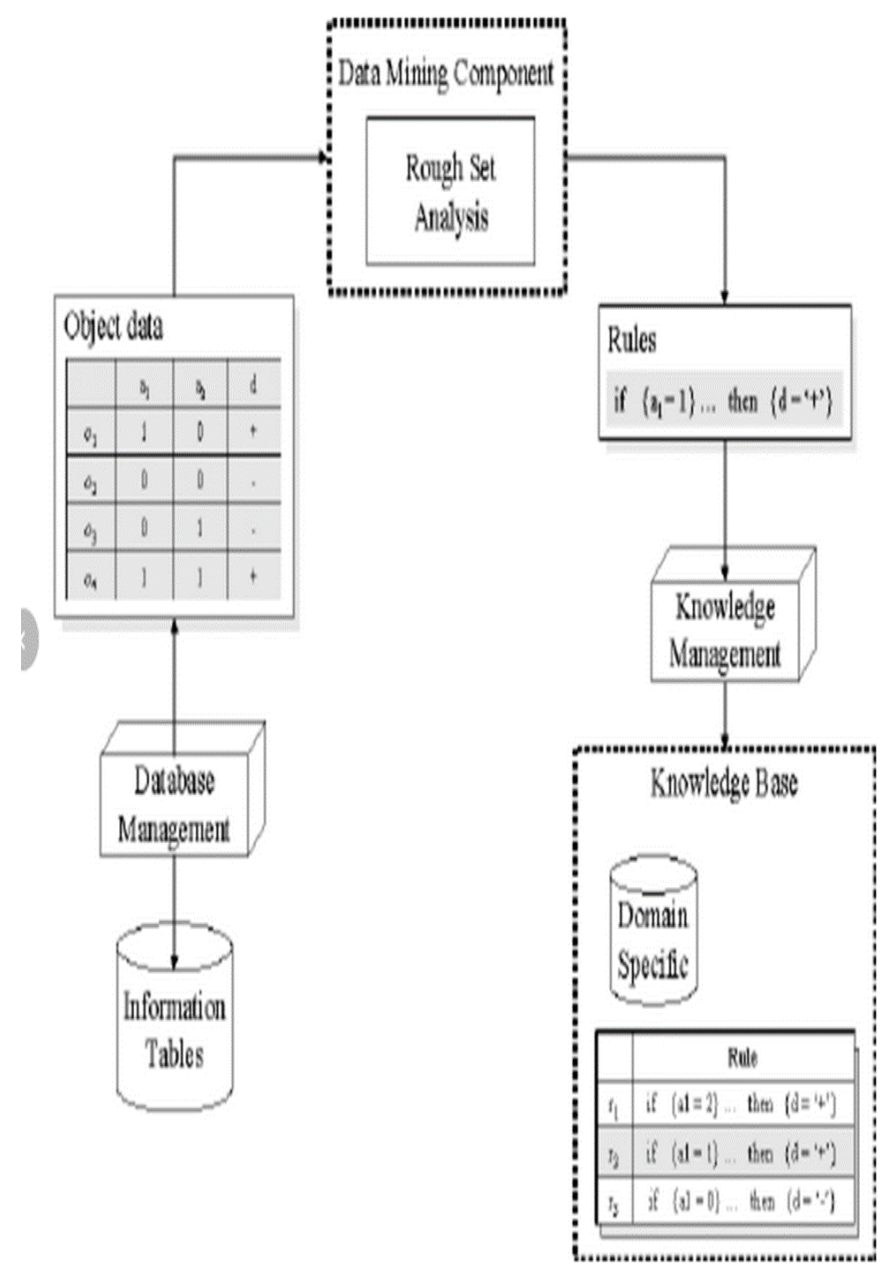

The values obtained in the Matlab code will be turned into an Information System. It will follow the Flow Chart stated above. The data would be turned into a knowledge base. Rough Set theory can be used to optimize the values. The optimization is done by following the algorithms in [33,34,35].

\section{ANALYSIS OF DATA}

For both the wye-connected and delta-connected systems, using the two-wattmeter method and three-wattmeter method of power measurement, translated into codes, can be similar to that in taking the line voltages and phase voltages respectively.

For the wye-connected system, a MATLAB function was created under the name 'wye'. The program asks the user to enter the values for the resistor elements under the variable names: 'Ra', 'Rb', and 'Rc'. After the program has stored the input, it then asks the user for the value of the three voltages, under the variable names ' $\mathrm{Va}$ ', ' $\mathrm{Vb}$ ', and ' $\mathrm{Vc}$ '. [36] Because using the two-wattmeter is the same for solving the value the line voltage, $\mathrm{Va}$ is multiplied by the square root of 3 in order to get Vac [37]. Once Vac has been acquired, it will be squared and divided by Ra to get the power when using the two-wattmeter method. For the three-wattmeter method, the voltage Va will be squared, multiplied by 3 , and then divided by $\mathrm{Ra}$. The power when using two-wattmeter and three-wattmeter method must yield the same results. In the example above, both methods yielded the same result of 6000 .

For the delta-connected system, a MATLAB function was also created. The program also asks the user to enter the values for the resistors and the voltages. For easier solving, the delta-connected system is converted to a wye-connected system by dividing the resistor value by 3 . After doing so, the program will proceed in solving for the power using both two-wattmeter and three-wattmeter the same way it did for the wye-connected system.

Figure 5: Rough Set Theory database flow chart [32] 


\section{CONCLUSION}

In conclusion, the two-wattmeter method is used to solve the power measurement of a three-phase wye-connected or delta-connected system. Based on the results of both delta and wye connected three-phase, three-wire systems, the two-wattmeter method yields the same results as the three wattmeter method. Although, the main disadvantage of the two wattmeters is that it could not be used for three-phase, four-wire systems. Meanwhile, three wattmeter method can be applied to both three-phase, three-wire and three-phase, four-wire systems. This is the reason why the programs made for this laboratory exercise are meant to be used for three-phase, three-wire systems that are either wye-connected or delta-connected only, given that this laboratory exercise mainly deals with the two-wattmeter method.

On the other hand, MATLAB was a helpful tool in solving for the power using two wattmeter and three wattmeter methods. The script files created for solving three-phase, three-wire wye-connected and delta-connected systems were able to show that both methods produce the same results despite using different formulas for each method. The program also allowed the users to input their own values for the resistor and voltage elements. The program also shows the power formulas used for each method, so that the users would know how the program came up with such results. It is to be noted though, that the program was only tested for balanced systems since unbalanced systems are said to be less efficient than balanced systems. For optimizing the system the Rough Set Theory can be used [38] with database optimization [39, 40].

\section{REFERENCES}

[1] R. Carritte, K. Cheung and M. Malik, "Alternative approaches and dynamic analysis considerations for detecting open phase conductors in three phase power systems," Electric Power Systems Research. Vol. 163, pp. 59-65, 2018. https://doi.org/10.1016/j.epsr.2018.05.012

[2] V. Leon-Martinez and J. Montañana-Romeu, "Formulations for the apparent and unbalanced power vectors in three-phase sinusoidal systems," Electric Power Systems Research. Vol. 160, pp. 37-43, 2018. https://doi.org/10.1016/j.epsr.2018.01.028

[3] E. Darwish, H. Hasanien, A. Atallah and S. El-Debeiky, "Reactive power control of three-phase low voltage system based on voltage to increase PV penetration levels," Ain Shams Engineering Journal. Vol. 9, No. 4, pp. 1831-1837, 2018. https://doi.org/10.1016/j.asej.2017.01.006

[4] W. Li, W. Liu, S. Liu, R. Ji and X. Zhang, "Impedance characteristics study of three-phase aircraft power wires," Measurement. Vol. 78, pp. 235-244, 2016. https://doi.org/10.1016/j.measurement.2015.10.020

[5] Wattmeter Connections. https://circuitglobe.com/two-wattmeter-method-of-powe r-measurement.html. 2019.
[6] L. Castro, J.H. Tovar-Hernández, N.González-Cabrera and J.R.Rodríguez-Rodríguez, "Real-power economic dispatch of AC/DC power transmission systems comprising multiple VSC-HVDC equipment," International Journal of Electrical Power \& Energy Systems. Vol. 107, pp. 140-148, 2019. https://doi.org/10.1016/j.ijepes.2018.11.018

[7] B. Singh and B. Gyanish, "Impact assessment of DG in distribution systems from minimization of total real power loss viewpoint by using optimal power flow algorithms," Energy Reports. Vol. 4, pp. 407-417, 2018. https://doi.org/10.1016/j.egyr.2018.07.003

[8] M. Mirz, S. Vogel, G. Reinke and A. Monti , "DPsim-A dynamic phasor real-time simulator for power systems," SoftwareX. Vol. 10, 2019. https://doi.org/10.1016/j.softx.2019.100253

[9] A. Africa, J. Aguilar, C. Lim Jr, P. Pacheco and S. Rodrin, "Automated Aquaculture System that Regulates $\mathrm{Ph}$, Temperature and Ammonia." 9th International Conference on Humanoid, Nanotechnology, Information Technology, Communication and Control, Environment, and Management (HNICEM). 2017. https://doi.org/10.1109/HNICEM.2017.8269494

[10] A. Africa, S. Bautista, F. Lardizabal, J. Patron and A. Santos, "Minimizing Passenger Congestion in Train Stations through Radio Frequency Identification (RFID) coupled with Database Monitoring System." ARPN Journal of Engineering and Applied Sciences. Vol. 12, No. 9, pp. 2863-2869, 2017.

[11]Z. Wang and Z. Guo, "On critical timescale of real-time power balancing in power systems with intermittent power sources." Electric Power Systems Research. Vol. 155, pp. 246-253, 2018. https://doi.org/10.1016/j.epsr.2017.10.022

[12] P. Balachennaiah, M.Suryakalavathi and P.Nagendra, "Firefly algorithm based solution to minimize the real power loss in a power system." Ain Shams Engineering Journal. Vol. 9, No. 1, pp. 89-100, 2018. https://doi.org/10.1016/j.asej.2015.10.005

[13]E. Mohagheghi, A. Gabash, M. Alramlawi and P. Li, "Real-time optimal power flow with reactive power dispatch of wind stations using a reconciliation algorithm." Renewable Energy. Vol. 126, pp. 509-523, 2018. https://doi.org/10.1016/j.renene.2018.03.072

[14]F. El-Faouri, M. Alzahlan, M. Batarseh, A. Mohammad and M. Za'ter, "Modeling of a microgrid's power generation cost function in real-time operation for a highly fluctuating load." Simulation Modelling Practice and Theory. Vol. 94, pp. 118-133, 2019. https://doi.org/10.1016/j.simpat.2019.01.002

[15] G. Ciulla, A. D'Amico, V. Di Dio and V. Lo Brano, "Modelling and analysis of real-world wind turbine power curves: Assessing deviations from nominal curve by neural networks." Renewable Energy. Vol. 140, pp. 477-492, 2019. https://doi.org/10.1016/j.renene.2019.03.075

[16] O. Sotnikov, M. Iasechko, V. Larin, O. Ochkurenko and D. Maksiuta, "The Model of a Medium for Creation of Electric Hermetic Screens of the Radio Electronic Means." International Journal of Advanced Trends in 
Computer Science and Engineering. Vol. 8, No. 2, pp. 300-303, 2019. https://doi.org/10.30534/ijatcse/2019/32822019

[17] Ch.R. Babu, T. Venkatesh, E. Jagadeeshwara Rao, U V Raju, "Conventional Full Adder FinFET Implementation using Transmission Gate logic." International Journal of Advanced Trends in Computer Science and Engineering. Vol. 7, No. 6, pp. 123-125, 2018. https://doi.org/10.30534/ijatcse/2018/11762018

[18] Wattmeter Method.

https://electricalbaba.com/two-wattmeter-method-power -measurement/. 2019.

[19] A. Africa, "A Logic Scoring of Preference Algorithm using ISO/IEC 25010:2011 for Open Source Web Applications Moodle and Wordpress." ARPN Journal of Engineering and Applied Sciences. Vol. 13, No.15, pp. 4567-4571, 2018.

[20] A. Africa, A. Mesina, J. Izon, and B. Quitevis, "Development of a Novel Android Controlled USB File Transfer Hub." Journal of Telecommunication, Electronic and Computer Engineering. Vol. 9, Nos. 2-8, pp. 1-5, 2017.

[21] M. Vopálenský, A. Platil and P. Kašpar, "Wattmeter with AMR sensor." Sensors and Actuators A: Physical. Vols. 123-124, pp. 303-307, 2005.

https://doi.org/10.1016/j.sna.2005.03.033

[22] A. Carullo, F..Ferraris, M. Parvis and A. Vallan, "An automatic calibrator for wattmeters with harmonic analysis capability." Measurement. Vol. 26, No. 4, pp. 263-271, 1999. https://doi.org/10.1016/S0263-2241(99)00050-0

[23]Z. Yan, Q. Fang, B. He, J. Huang and Z. Lin, "The considerations and guides of the wattmeter method for measuring output acoustical power of Langevin-type transducers - I: theory." Ultrasonics. Vol. 35, No. 7, pp. 533-541, 1997. https://doi.org/10.1016/S0041-624X(97)00026-7

[24] M. Sung and I. Mudawar, "Single-phase and two-phase heat transfer characteristics of low temperature hybrid micro-channel/micro-jet impingement cooling module." International Journal of Heat and Mass Transfer. Vol. 51, Nos. 15-16, pp. 3882-3895, 2008. https://doi.org/10.1016/j.ijheatmasstransfer.2007.12.016

[25]P. Loresco and A. Africa, "ECG Print-out Features Extraction Using Spatial-Oriented Image Processing Techniques." Journal of Telecommunication, Electronic and Computer Engineering. Vol. 10, Nos. 1-5, pp. 15-20, 2018.

[26] A. Africa and J. Velasco, "Development of a Urine Strip Analyzer using Artificial Neural Network using an Android Phone." ARPN Journal of Engineering and Applied Sciences. Vol. 12, No. 6, pp. 1706-1712, 2017.

[27] H. Pourrahmani, M. Siavashi and M. Moghimi, "Design optimization and thermal management of the PEMFC using artificial neural networks." Energy. 2019. https://doi.org/10.1016/j.energy.2019.06.019

[28] S. Brucal, A. Africa and E. Dadios, "Female Voice Recognition using Artificial Neural Networks and MATLAB Voicebox Toolbox." Journal of
Telecommunication, Electronic and Computer Engineering. Vol. 10, Nos. 1-4, pp. 133-138, 2018.

[29] P. Hilletofth, M. Sequeira and A. Adlemo, "Three novel fuzzy logic concepts applied to reshoring decision-making." Expert Systems with Applications. Vol. 126, pp. 133-143, 2019.

https://doi.org/10.1016/j.eswa.2019.02.018

[30] A. Africa, "A Mathematical Fuzzy Logic Control Systems Model Using Rough Set Theory for Robot Applications." Journal of Telecommunication, Electronic and Computer Engineering. Vol. 9, No. 2-8, pp. 7-11, 2017.

[31] Z. Palwak, "Risk Analysis Technique on Inconsistent Interview Big Data Based on Rough Set Approach." International Journal of Computer and Information Science. Vol. 11, pp. 341-356, 1982.

[32] J. Yao and J. Herbert, "Web based Support Systems with Rough Set Analysis." Rough Sets and Intelligent Systems Paradigm International Conference, 2007.

[33] A. Africa and M. Cabatuan, "A Rough Set Based Data Model for Breast Cancer Mammographic Mass Diagnostics." International Journal of Biomedical Engineering and Technology. Vol. 18, No. 4, pp. 359-369, 2015. https://doi.org/10.1504/IJBET.2015.071010

[34] A. Africa, "A Rough Set Based Solar Powered Flood Water Purification System with a Fuzzy Logic Model." ARPN Journal of Engineering and Applied Sciences. Vol. 12, No. 3, pp. 638-647, 2017.

[35] A. Africa, "A Rough Set-Based Expert System for diagnosing information system communication networks." International Journal of Information and Communication Technology. Vol. 11, No. 4, pp. 496-512, 2017. https://doi.org/10.1504/IJICT.2017.10008315

[36] S.T. Hwang, H.M. Soliman and R.T. Lahey Jr, "Phase separation in impacting wyes and tees." International Journal of Multiphase Flow. Vol. 15, No. 6, pp. 965-975, 1989. https://doi.org/10.1016/0301-9322(89)90024-4

[37] N. Yang and W. Tseng, "Adaptive three-phase power-flow solutions for smart grids with plug-in hybrid electric vehicles." International Journal of Electrical Power \& Energy Systems. Vol. 64, pp. 1166-1175, 2015. https://doi.org/10.1016/j.ijepes.2014.08.007

[38] A. Africa, "A Rough Set Data Model for Heart Disease diagnostics." ARPN Journal of Engineering and Applied Sciences. Vol. 11, No.15, pp. 9350-9357, 2016.

[39] M. Tawarish and K. Satyanarayana, "A Review on Pricing Prediction on Stock Market by Different Techniques in the Field of Data Mining and Genetic Algorithm." International Journal of Advanced Trends in Computer Science and Engineering (IJATCSE). Vol. 8, No. 1, pp. 23-26, 2019. https://doi.org/10.30534/ijatcse/2019/05812019

[40] D. Ahamad, M. Akhtar and S. Hameed, "A Review and Analysis of Big Data and MapReduce." International Journal of Advanced Trends in Computer Science and Engineering (IJATCSE). Vol. 8, No. 1, pp. 1-3, 2019. https://doi.org/10.30534/ijatcse/2019/01812019 